\title{
PENDIDIKAN KARAKTER DI KELUARGA
}

\author{
Ahmad Zainuri \\ Dosen Fakultas Ilmu \\ Tarbiyah dan Keguruan \\ UIN Raden Fatah \\ Palembang
}

azainuri169@gmail.com

\begin{abstract}
Family is the first and foremost environment for a human child. In the family a child is raised, learns the ways of association that he will develop later in the social life environment that is outside the family. In simple terms it can be argued that the function of the family is to stabilize the family situation in the sense of stabilizing the family's economic situation. Then the family functions also educate and maintain the physical and psychological family, including religious life.

Here the role of parents, especially mothers, is very influential on the development of the child. Family education is called primary education because in this environment all human potential is formed and partially developed. There are even some potentials that have developed in family education. Children will grow up to be characterless individuals if they can grow in a characteristic environment, so that the nature of every child born holy can develop optimally. Character education must start from the family to build a noble national personality. To achieve the child's character expected by parents, parenting given by the family to children is closely related to the character of the child in his growth and development. These characters will be carried to adulthood even if they form their own family.

On the contrary, family failure in shaping children's character will result in the growth of a society that has no character. Therefore, every family must have an awareness that the formation of children's character is very dependent on character education at home. Furthermore, Megawangi (2003) mentions that there are at least three basic children's needs that must be met, namely maternal bonding, security, and physical and mental stimulation.
\end{abstract}

Keywords: Character Education, Family. 


\section{PENDAHULUAN}

Keluarga berasal dari bahasa Sanskerta; "kulawarga"; "ras" dan "warga" yang berarti "anggota") adalah lingkungan yang terdapat beberapa orang yang masih memiliki hubungan darah. Keluarga adalah unit terkecil dari masyarakat yang terdiri atas kepala keluarga dan beberapa orang yang terkumpul dan tinggal di suatu tempat di bawah suatu atap dalam keadaan saling ketergantungan (id.wikipedia. org/wiki/Keluarga). Menurut Salvicion dan Celis (1998) di dalam keluarga terdapat dua atau lebih dari dua pribadi yang tergabung karena hubungan darah, hubungan perkawinan atau pengangkatan, di hidupnya dalam satu rumah tangga, berinteraksi satu sama lain dan di dalam perannya masingmasing dan menciptakan serta mempertahankan suatu kebudayaan (Baron, R. A dan Donn Byrne, 2003). Keluarga merupakan bagian masyarakat yang fundamental bagi kehidupan pembentukan kepribadian anak manusia. Hal ini diungkapkan Syarief Muhidin (1981: 52) yang mengemukakan bahwa "tidak ada satupun lembaga kemasyarakatan yang lebih efektif di dalam membentuk keperibadian anak, selain keluarga. Keluarga tidak hanya membentuk anak secara fisik tetapi juga berpengaruh secara psikologis".

Pendapat di atas dapat dimungkinkan karena keluarga merupakan lingkungan pertama dan utama bagi seorang anak manusia. Di dalam keluarga seorang anak dibesarkan, mempelajari cara-cara pergaulan yang akan dikembangkannya kelak di lingkungan kehidupan sosial yang ada di luar keluarga. Dengan perkataan lain, di dalam keluarga seorang anak dapat memenuhi kebutuhan-kebutuhannya, baik kebutuhan fisik, psikis maupun sosial, sehingga mereka dapat tumbuh dan berkembang dengan baik. Di samping itu pula seorang anak memperoleh pendidikan yang berkenaan dengan nilai-nilai maupun normanorma yang ada dan berlaku di masyarakat ataupun dalam keluarganya sendiri serta cara-cara untuk menyesuaikan diri dengan lingkungannya.

Sedangkan istilah keluarga itu sendiri memiliki beraneka ragam pengertian, salah satunya diungkapkan oleh Paul B Houton dan Chester L Hunt (1987: 267) adalah sebagai berikut:

a) Suatu kelompok yang mempunyai nenek moyang yang sama;

b) Suatu kelompok kekerabatan yang disatukan oleh darah atau perkawinan;

c) Pasangan perkawinan dengan atau tanpa anak; 
d) Pasangan tanpa nikah yang mempunyai anak; dan

e) Satu orang dengan beberapa anak.

Karena beragam dan luasnya pengertian tentang keluarga maka penting adanya pembatasan atau definisi keluarga. Di antaranya pendapat Burgess dan Lock yang membedakan keluarga dengan kelompok sosial lainnya. Keluarga adalah susunan orang-orang yang disatukan oleh ikatan-ikatan perkawinan, darah atau adopsi. Pertalian antara suami dan istri adalah perkawinan dan hubungan antara orang tua dan anak biasanya adalah darah atau kadangkala adopsi.

Anggota-anggota keluarga ditandai dengan hidup bersama dibawah satu atap dan merupakan susunan satu rumah tangga, kadang-kadang seperti masa lampau rumah tangga adalah keluarga luas, meliputi didalamnya empat sampai lima generasi. Sekarang rumah tangga semakin kecil ukurannya, umumnya dibatasi oleh suami istri anak atau dengan satu anak, dua atau tiga anak.

Di dalam keluarga sebagai satu kesatuan dari orang-orang yang berinteraksi dan berkomunikasi yang menciptakan peranan-peranan sosial bagi si suami dan istri, ayah dan ibu, putra dan putri, saudara laki-laki dan saudara perempuan. Peranan-peranan tersebut dibatasi oleh masyarakat, tetapi masing-masing keluarga diperkuat melalui sentimen-sentimen yang sebagian merupakan tradisi dan sebagian lagi emosional yang menghasilkan pengalaman.

Dengan demikian, keluarga adalah pemelihara suatu kebudayaan bersama yang diperoleh pada hakekatnya dari kebudayaan umum, tetapi dalam suatu masyarakat yang kompleks masing-masing keluarga mempunyai ciri-ciri yang berlainan dengan keluarga lain. Berbeda kebudayaan dari setiap keluarga timbul melalui komunikasi anggota-anggota keluarga yang merupakan gabungan dari pola-pola tingkah laku individu (Khairudin, 1985).

Pada garis besarnya keluarga dapat dibagi kedalam dua bentuk besar yaitu keluarga luas (extended family) dan keluarga inti (nuclear family). Keluarga luas adalah satuan keluarga yang meliputi lebih dari satu generasi dan satu lingkungan kaum keluarga yang lebih luas daripada hanya ayah, ibu dan anak-anak atau dengan perkataan lain, keluarga luas merupakan keluarga inti ditambah dengan anggota-anggota keluarga yang lain, atau keluarga yang lebih dari satu generasi. Sedangkan keluarga inti dapat didefinisikan dengan keluarga atau kelompok yang terdiri dar atah, ibu dan anak-anak yang belum dewasa atau belum menikah. Di 
Indonesia sendiri, keluarga telah diatur dalam berbagai peraturan atau undangundang RI Nomor 10 tahun 1992 mendefinisikan keluarga sebagai berikut: "Keluarga merupakan wahana pertama seorang anak mendapatkan pengetahuan dan keterampilan yang diperlukan bagi kelangsungan hidupnya”.

\section{Fungsi Pokok Keluarga}

Pada dasarnya keluarga mempunyai fungsi-fungsi pokok yang sulit diubah dan digantikan oleh orang atau lembaga lain tetapi karena masyarakat sekarang ini telah mengalami perubahan, tidak menutup kemungkinan sebagian dari fungsi sosial keluarga tersebut mengalami perubahan. Dalam pelaksanaan fungsi-fungsi keluarga tersebut akan banyak dipengaruhi oleh ikatan-ikatan dalam keluarga, hal ini sesuai dengan yang dikatakan MI Solaeman (1978: 18) bahwa pada dasarnya keluarga mempunyai fungsi-fungsi yang pokok, yaitu fungsi-fungsi yang tidak bisa dirubah dan digantikan oleh orang lain, sedangkan fungsi-fungsi lain atau fungsi-fungsi sosial relatif lebih mudah berubah atau mengalami perubahan.

Mengenai fungsi keluarga Abu Ahmadi (1991: 247) mengemukakan bahwa tugas atau fungsi keluarga bukan merupakan fungsi yang tunggal tetapi jamak. Secara sederhana dapat dikemukakan bahwa fungsi kelurga adalah menstabilkan situasi keluarga dalam arti stabilisasi situasi ekonomi keluarga. Kemudian fungsi keluarga juga mendidik dan memelihara fisik dan psikis keluarga, termasuk kehidupan religius. Selanjutnya, mengenai fungsi keluarga, khususnya tanggung jawab orang tua terhadap anaknya. Singgih P Gunarsa (1991: 54) mengemukakan bahwa tanggung jawab orang tua ialah memenuhi kebutuhan-kebutuhan si anak baik dari sudut organis-psikologis, antara lain, makanan, maupun kebutuhankebutuhan psikis seperti kebutuhan-kebutuhan akan perkembangan, kebutuhan intelektual melalui pendidikan, kebutuhan rasa dikasihi, dimengerti dan rasa aman melalui perawatan asuhan ucapan-ucapan dan perlakuan.

Dari konsep tersebut diterangkan bahwa diantaranya peran orang tua ini sangat penting sekali terhadap pemenuhan kebutuhan intelektual bagi anak melalui pendidikan. Hal ini merupakan tanggung jawab orang tua harus diberikan kepada anaknya sehingga orang tua ditekankan harus mengerti akan fungsi keluarga dan tentunya pemahaman tentang pendidikan. Ini harus benar-benar dirasakan oleh orang tua sampai mampu berkeinginan untuk melanjutkan sekolah 
anaknya ke jenjang yang lebih tinggi, sehingga wawasan dan pemahaman anak bisa lebih luas.

Menurut Nur'aeni (2010) ada delapan fungsi pokok keluarga, yakni:

Fungsi Edukatif. Keluarga sebagai suatu unsur dari tingkat pusat pendidikan merupakan lingkungan pendidikan yang pertama bagi anak. Dalam kedudukan ini merupakan suatu yang wajar apabila kehidupan keluarga sehari-hari, pada saarsaat tertentu terjadi situasi pendidikan yang dihayati oleh anak dan diarahkan pada perbuatan-perbuatan yang sesuai dengan tujuan pendidikan.

Fungsi edukasi ini terkait dengan pendidikan anak secara khusus dan pembinaan anggota keluarga pada umumnya. Ki Hajar Dewantara menyebutkan bahwa "keluarga adalah pusat pendidikan yang utama dan pertama bagi anak". Fungsi pendidikan amat fundamental untuk menanamkan nilai-nilai dan sistem perilaku manusia dalam keluarga.

Fungsi Sosialisasi. Melalui interaksi dalam keluarg anak mempelajari pola-pola tingkah laku, sikap, keyakinan, cita-cita serta nilai-nilai dalam masyarakat dalam rangka pengembangan kepribadiannya. Dalam rangka melaksanakan fungsi sosialisasi ini, keluarga mempunyai kedudukan sebagai penghubung antara anak dengan kehidupan sosial dan norma-norma sosial yang meliputi penerangan, penyaringan dan penafsiran ke dalam bahasa yang dimengerti oleh anak.

Fungsi sosialisasi ini bertujuan untuk mempersiapkan anak menjadi anggota masyarakat. Anak adalah pribadi yang memiliki sifat kemanusiaan sebagai makhluk individu dan juga sebagai makhluk sosial. Menarik untuk memaknai pendapat Karl Mannheim yang dikutip oleh MI Soelaeman (1994), bahwa "anak tidak didik dalam ruang dan keadaan yang abstrak, melainkan selalu di dalam dan diarahkan kepada kehidupan masyarakat tertentu". Dengan demikian, anak memiliki prinsip sosialitas, di samping prinsip individualitas. Prinsip sosialitas, mengharuskan anak dibawa dan diarahkan untuk mengenali nilai-nilai sosial lingkungannya oleh orang tuanya.

Fungsi Protektif. Fungsi ini lebih menitik beratkan dan menekankan kepada rasa aman dan terlindungi. Apabila anak merasa aman dan terlindungi barulah anak dapat bebas melakukan penjajagan terhadap lingkungan.Tujuan dari fungsi proteksi ini untuk melindungi anak bukan saja secara fisik, melainkan pula secara psikis. Secara fisik fungsi perlindungan ditujukan untuk menjaga pertumbuhan 
biologisnya sehingga dapat menjalankan tugas secara proporsional. Di samping itu, fungsi proteksi psikis dan spiritual yaitu dengan mengendalikan anak dari pergaulan negatif dan sikap lingkungan yang cenderung menekan perkembangan psikologinya.

Fungsi Afeksional. Yang dimaksud dengan fungsi afeksi adalah adanya hubungan sosial yang penuh dengan kemesraan dan afeksi. Anak biasanya mempunyai kepekaan tersendiri akan iklim-iklim emosional yang terdapat dalam keluarga. Kehangatan dalam keluarga akan membantu proses perkembangan keperibadian anak. Fungsi ini terkait dengan emosional anak. Anak akan merasa nyaman apabila mampu melakukan komunikasi dengan keluarganya dengan totalitas seluruh kepribadiannya. Kasih sayang yang dicurahkan kepada anak akan memberi kekuatan, dukungan atas kehidupan emosionalnya yang berpengaruh pada kualitas hidupnya di masa depan.

Fungsi Religius. Keluarga berkewajiban memperkenalkan dan mengajak anak serta keluarga pada kehidupan beragama. Sehingga melalui pengenalan ini diharapkan keluarga dapat mendidik anak serta anggotanya menjadi manusia yang beragama sesuai dengan keyakinan keluarga tersebut.

Fungsi Ekonomis. Fungsi keluarga ini meliputi pencarian nafkah, perencanaan dan pembelanjaannya. Pelaksanaanya dilakukan oleh dan untuk semua anggota keluarga, sehingga akan menambah saling mengerti, solidaritas dan tanggung jawab bersama. Fungsi ini berkaitan dengan pemenuhan selayaknya kebutuhan yang bersifat materi. Secara normatif anak harus dipersiapkan agar kelak memikul tanggung jawab ekonomi keluarga, membangun kepribadian yang mandiri bukan menjadi objek pemaksaan orang tua.

Fungsi Rekreatif. Suasana keluarga yang tenteram dan damai diperlukan guna mengembalikan tenaga yang telah dikeluarkan dalam kehidupan sehari-hari. Memberikan wahana dan situasi yang memungkinkan terjadinya kehangatan, keakraban, kebersamaan dan kebahagiaan bersama seluruh anggota keluarga.

Fungsi Biologis. Fungsi ini berhubungan dengan pemenuhan kebutuhankebutuhan biologis keluarga, di antaranya kebutuhan seksual. Kebutuhan ini berhubungan dengan pengembangan keturunan atau keinginan untuk mendapatkan keturunan. Selain itu juga yang termasuk dalam fungsi biologis ini yaitu perlindungan fisik seperti kesehatan jasmani dan kebutuhan jasmani yaitu 
dengan terpenuhinya kebutuhan sandang, pangan dan papan akan mempengaruhi kepada jasmani setiap anggota keluarga.

Dari uraian mengenai fungsi-fungsi keluaga di atas, maka dapat dikatakan bahwa fungsi-fungsi ini semuanya memegang peranan penting dalam keluarga, terutama dalam meningkatkan kesejahteraan individu yang menjadi anggota keluarganya. Untuk itu dalam penerapannya hendaknya fungsi-fungsi tersebut berjalan secara seimbang, karena akan membantu keharmonisan serta kehidupan keluarga. Pelaksanaan fungsi-fungsi keluarga ini disertai dengan suasana yang baik serta fasilitas yang memadai.

\section{Pendidikan dalam Keluarga}

Kata pendidikan menurut etimologi berasal dari kata dasar didik. Apabila diberi awalan me, menjadi mendidik, maka akan membentuk kata kerja yang berarti memelihara dan memberi latihan (ajaran). Sedangkan bila berbentuk kata benda akan menjadi pendidikan yang memiliki arti proses perubahan sikap dan tingkah laku seseorang atau sekelompok orang dalam usaha mendewasakan manusia melalui upaya pengajaran dan latihan.

Pendidikan di Indonesia pada awalnya didasari oleh pendidikan yang diterapkan dalam lingkungan keluarga. Di mana keluarga mengajarkan moral yang nantinya akan diterapkan anak dan menjadi dasar kepribadiannya pada masa dewasa kelak. Keluarga ibarat cetakan awal dari segala aktivitas yang akan dilaksanakan dalam hari hari selanjutnya. Dalam keluarga inilah pertama kali pendidikan itu dilaksanakan.

Masih ingat jelas saat kita dilahirkan, jangan kan ilmu IPA dan Matematika, Membaca huruf A saja tidak bisa, Nah, dilingkungan keluarga inilah semua cetakan ini berawal. Maka dari itu keluarga memiliki peran penting dalam mendidik anaknya. Keluarga berhak mengawasi apa saja yang boleh dilakukan si anak dan yang tidak boleh dilakukannya. Biasanya keluarga selalu mengajarkan moral dan tata susila dasar kepada sang anak, karena itulah dasar dari segala pembelajaran yang ada. Percuma memiliki kepintaran yang tinggi jika tidak mengerti kesopanan dan moralitas. Dalam hal ini keluarga adalah cetakan awal dari sebuah pendidikan.

Anak yang diserahkan kepada sekolah untuk dididik bukan berarti tanggung jawab pendidikan itu berada pada sekolah, akan tetapi keluarga juga harus turut 
berperan dalam mendidik anak yang sedang berkembang. Keluarga bertanggung jawab atas anak-anaknya baik di rumah maupun di sekolah.

Dalam psikologi pendidikan, pendidikan yang paling banyak berperan penting dalam pembentukan moral anak adalah keluarga. Keluarga yang pertama kali menanamkan moral yang nantinya juga akan menjadi fondasi kepribadian anak. Begitu juga dengan pendidikan yang diberikan oleh sekolah, pendidikan tersebut tidak akan berjalan apabila keluarga tidak berperan dalam pengaplikasiannya di kehidupan sehari-hari anak. Apabila lingkungan keluarga baik, maka baik juga anak tersebut. Namun, apabila lingkungannya buruk, buruk jugalah anak tersebut walaupun sang anak telah mendapatkan pelajaran yang baik dari lngkungan sekolah.

Lingkungan keluarga menjadi faktor penting dalam menanamkan dan membentuk kepribadian anak. Peran lingkungan keluarga dalam mewujudkan kepribadian seseorang, baik lingkungan pra kelahiran maupun lingkungan pasca kelahiran adalah masalah yang tidak bisa dipungkiri keberadaannya. Sebab diyakini lingkungan keluarga adalah sebuah basis awal kehidupan bagi setiap manusia. Keluarga menyiapkan sarana pertumbuhan dan pembentukan kepribadian anak sejak dini. Dengan kata lain, kepribadian anak tergantung pada pemikiran dan perlakuan kedua orang tua dan lingkungannya,

Keluarga merupakan lembaga pendidikan bersifat informal, yang pertama dan utama dialami oleh anak serta lembaga pendidikan yang bersifat kodrati orang tua bertanggung jawab memelihara, merawat, melindungi, dan mendidik anak agar tumbuh dan berkembang dengan baik. Di sini peranan oang tua terutama ibu sangatlah berpengaruh terhadap perkembangan anak tersebut. Pendidikan keluarga disebut pendidikan utama karena di dalam lingkungan ini segenap potensi yang dimiliki manusia terbentuk dan sebagian dikembangkan. Bahkan ada beberapa potensi yang telah berkembang dalam pendidikan keluarga.

Pendidikan keluarga dapat dibedakan menjadi dua bagian. Pertama, pendidikan prenatal (pendidikan sebelum lahir) merupakan pendidikan yang berlangsung selama anak belum lahir atau masih dalam kandungan. Pendidikan prenatal lebih dipengaruhi kepada kebudayaan lingkungan setempat. Dalam kehidupan yang lebih modern sekarang ini, terdapat pula model pendidikan prenatal. Seperti mendengarkan lagu-lagu klasik selama anak masih dalam 
kandungan, melakukan pemerikasaan rutin ke dokter kandungan atau mengkonsumsi nutrisi yang baik bagi si jabang bayi.

Secara sederhana pendidikan prenatal dalam keluarga bertujuan untuk menjamin agar si jabang bayi sehat selama dalam kandungan hingga nanti pada akhirnya dapat terlahir dengan proses yang lancar dan selamat.

Kedua, pendidikan postnatal (pendidikan setelah lahir). Pendidikan postnatal merupakan pendidikan manusia dalam lingkungan keluarga di mulai dari manusia lahir hingga akhir hayatnya. Segala macam ilmu kehidupan yang diperoleh dari keluarga merupakan hasil dari proses pendidikan keluarga postnatal. Dari manusia lahir sudah diajari bagaimana caranya tengkurap, minum, makan, berjalan hingga tentang ilmu agama. pada dasarnya sebuah keluarga akan banyak memberi pendidikan dibidang sosial dan moral kepada sang anak sebab itu merupakan pondasi dari sebuah pendidikan yang sebenarnya. Dari hal terkecil sang anak telah mewarisi sebuah pembelajaran moral dari sebuah keluarga. Misalnya, makan dengan tangan kanan, tidak meludah disembarang tempat, dan harus menghormati tamu. Itu adalah pelajaran awal dari sebuah keluarga. Pendidikan selalu berawal dari ruang lingkup keluarga.

Karena itu tidak berlebihan bila dikatakan lembaga keluarga merupakan pendidikan yang pertama yang didapat oleh anak. Lingkungan pendidikan yang pertama membawa pengaruh terhadap anak untuk melanjutkan pendidikan yang akan dialaminya di sekolah dan di masyarakat. Motivasi pendidikan keluarga semata-mata demi cinta kasih sayang, di mana di dalamnya terdapat suasana cinta inilah proses pendidikan berlangsung seumur anak-anak itu dalam tanggung jawab orang tua/keluarga. Mereka tidak hanya berkewajiban mendidik atau menyekolahkan anaknya ke sebuah lembaga pendidikan. Akan tetapi mereka juga diamati Allah SWT untuk menjadikan anak-anaknya bertaqwa serta taat beribadah sesuai dengan ketentuan yang telah diatur dalam al-Qur'an dan hadits.

Jadi, orang tua seharusnya tidak hanya menyerahkan sepenuhnya pendidikan anak mereka kepada pihak lembaga pendidika atau sekolah, akan tetapi mereka harus lebih memperhatikan pendidikan anak-anak mereka di lingkungan keluarga mereka, karena keluarga merupakan faktor yang utama di dalam proses pembentukan kepribadian sang anak. Orang tua merupakan pribadi 
yang sering ditiru anak-anaknya. Dengan demikian keteladanan yang baik merupakan salah satu kiat yang harus diterapkan dalam mendidik anak.

Menurut Quraish Shihab (1983) "Keluarga adalah tiang negara, jiwa masyarakat dan tulang punggungnya kesejahteraan lahir dan batin yang dinikmati oleh suatu bangsa, atau sebaliknya kebodohan dan keterbelakangannya adalah cerminan dari keluarga yang hidup pada masyarakat /lingkungan". Pendidikan merupakan proses di mana seseorang diberi kesempatan menyesuaikan diri terhadap aspek kehidupan. Lingkungan yang berkaitan dengan kehidupan seorang anak dalam menentukan kepribadiannya yang baik.

Seorang filsuf, Imam al-Ghazali mengatakan "orang tua sebagai pendidik adalah melatih anak-anak sebagai amanat bagi orang tua. Hati anak suci bagaikan mutiara cemerlang, bersih dari segala yang diukirkan atasnya dan juga condong". Kewajiban orang tua dalam keluarga mendidik dan membimbing anak-anaknya serta memelihara dan melindungi dari gangguan baik di luar lingkungan dan di dalam lingkungan. Dari itulah sebagai orang tua harus benar-benar mendidik anaknya, agar mereka menjadi anak-anak yang diharapkan oleh keluarga. Tanpa dukungan keluarga atau orang tua mereka tidak akan menjadi anak yang berakhlak mulia.

\section{Pola Asuh dan Pendidikan Karakter}

Menurut David Elkind \& Freddy Sweet (2004), character education is the deliberate effort to help people understand, care about, and act upon core ethical values. When we think about the kind of character we want for our children, it is clear that we want them to be able to judge what is right, care deeply about what is right, and then do what they believe to be right, even in the face of pressure from without and temptation from within. Di sini, David Elkind \& Freddy Sweet mengemukakan bahwa pendidikan karakter merupakan usaha sengaja untuk membantu orang memahami, peduli, dan bertindak berdasarkan nilai-nilai etika inti. Sedangkan pendidikan karakter dalam keluarga merupakan usaha yang dilakukan orang tua untuk mendidik anak agar mempunyai karakter berdasarkan nilai-nilai etika.

Ketika orang tua berpikir tentang jenis karakter untuk anak-anaknya, jelas bahwa mereka ingin anak yang mempunyai karakter yang diharapkan orang tua. Namun di sisi lain, kadang orang tua menghendaki karakter yang dimiliki anak 
yang tumbuh dari dirinya sendiri. Menurut Thomas Lickona, pendidikan karakter adalah pendidikan budi pekerti plus, yaitu melibatkan aspek pengetahuan (cognitive), perasaan (feeling), dan tindakan (action). Tanpa ketiga aspek ini, maka pendidikan karakter tidak akan efektif, dan pelaksanaannya pun harus dilakukan secara sistematis dan berkelanjutan.

Menurut resolusi Majelis Umum PBB (dalam Megawangi, 2003), fungsi utama keluarga adalah "sebagai wahana untuk mendidik, mengasuh, dan mensosialisasikan anak, mengembangkan kemampuan seluruh anggotanya agar dapat menjalankan fungsinya di masyarakat dengan baik, serta memberikan kepuasan dan lingkungan yang sehat guna tercapainya keluarga, sejahtera”. Keluarga merupakan aspek penting untuk menanamkan karakter pada anak sehingga anak mempunyai karakter yang baik dan diharapkan orangtua. Setiap keluarga mempunyai tujuan dan karakter yang berbeda. Oleh karena itu, keluarga mempunyai cara masing-masing untuk menanamkan maupun meningkatkan karakter pada anak.

Selanjutnya, Megawangi (2003) mengatakan bahwa anak-anak akan tumbuh menjadi pribadi yang berkarakter apabila dapat tumbuh pada lingkungan yang berkarakter, sehingga fitrah setiap anak yang dilahirkan suci dapat berkembang segara optimal. Pendidikan karakter harus dimulai dari keluarga untuk membangun kepribadian bangsa yang mulia. Untuk mencapai karakter anak yang diharapkan oleh orang tua, pola asuh yang diberikan keluarga kepada anak-anak sangat berkaitan erat dengan karakter anak dalam tumbuh kembangnya. Karakter tersebut akan terbawa sampai dewasa bahkan sampai mereka membentuk keluarga sendiri.

Anak-anak memiliki dunianya sendiri. Hal itu ditandai dengan banyaknya gerak, penuh semangat, suka bermain pada setiap tempat dan waktu, tidak mudah letih, dan cepat bosan. Anak-anak memiliki rasa ingin tahu yang besar dan selalu ingin mencoba segala hal yang dianggapnya baru. Anak-anak hidup dan berpikir untuk saat ini, sehingga ia tidak memikirkan masa lalu yang jauh dan tidak pula masa depan yang tidak diketahuinya. Oleh sebab itu, seharusnya orang tua dapat menjadikan realitas masa sekarang sebagai titik tolak dan metode pembelajaran bagi anak. (Zurayk, 1997). 
Keluarga memang mempunyai peran penting untuk membangun karakter anak. Namun anak juga berhak menentukan dunianya sendiri sehingga terbentuk suatu karakter pada diri anak. Apabila karakter pada anak buruk, keluarga wajib untuk mengarahkan dan menanamkan karakter baik pada anak. Sehingga anak mempunyai karakter baik yang berguna untuk masa dewasanya. Upaya yang dilakukan oleh orangtua dalam membangun karakter anak usia dini yaitu:

1. Memperlakukan anak sesuai dengan karakterisktik anak

2. Memenuhi kebutuhan dasar anak, yaitu kebutuhan kasih sayang dan pemberian makanan yang bergizi

3. Memberikan dukungan dan penghargaan ketika anak menampilkan tingkah laku yang baik dan sebaliknya, memberikan pengertian dan mengarahkan ketika anak menampilkan tingkah laku yang buruk.

4. Memberikan fasilitas lingkungan yang sesuai dengan usia perkembangannya, hal ini merupakan salah satu fungi keluarga yaitu keluarga sebagai fasilitator.

5. Bersikap tegas, konsisten dan bertanggung jawab. Orangtua wajib bersikap tegas untuk mengarahkan anak agar anak mengerti akan tanggung jawabnya.

Menurut Megawangi (2003), penanaman kualitas pendidikan karakter pada anak meliputi sembilan pilar, yaitu;

1. Cinta Tuhan dan segenap ciptaanNya

2. Tanggung jawab

3. Disiplin dan Mandiri

4. Hormat dan Santun

5. Dermawan, Suka menolong dan Gotong royong

6. Percaya diri, Kreatif dan Pekerja keras

7. Kepemimpinan dan Adil

8. Baik dan Rendah hati

9. Toleran, cinta damai dan kesatuan

Nilai-nilai dan kualitas karakter inilah sejak dini harus benar-benar ditanamkan pada anak dalam keluarga. Karenanya, pakar pendidikan, William Bennett (dalam Megawangi, 2003), mengatakan apabila keluarga gagal untuk mengajarkan kejujuran, semangat, keinginan untuk menjadi yang terbaik, dan kemampuan-kemampuan dasar, maka akan sulit sekali bagi institusi-institusi lain untuk memperbaiki kegagalan-kegagalannya. 
Kegagalan keluarga dalam membentuk karakter anak akan berakibat pada tumbuhnya masyarakat yang tidak berkarakter. Oleh karena itu, setiap keluarga harus memiliki kesadaran bahwa pembentukan karakter anak sangat tergantung pada pendidikan karakter di rumah. Lebih jauh, Megawangi (2003) menyebutkn setidaknya ada tiga kebutuhan dasar anak yang harus dipenuhi, yaitu maternal bonding, rasa aman, dan stimulasi fisik dan mental.

Maternal bonding (kelekatan psikologis dengan ibunya) merupakan dasar penting dalam pembentukan karakter anak karena aspek ini berperan dalam pembentukan dasar kepercayaan kepada orang lain (trust) pada anak. Kelekatan ini membuat anak merasa diperhatikan dan menumbuhkan rasa aman sehingga menumbuhkan rasa percaya. Menurut Erikson, dasar kepercayaan yang ditumbuhkan melalui hubungan ibu-anak pada tahun-tahun pertama kehidupan anak akan memberi bekal bagi kesuksesan anak dalam kehidupan sosialnya ketika ia dewasa. Dengan kata lain, ikatan emosional yang erat antara ibu-anak di usia awal dapat membentuk kepribadian yang baik pada anak.

Kebutuhan akan rasa aman yaitu kebutuhan anak akan lingkungan yang stabil dan aman. Kebutuhan ini penting bagi pembentukan karakter anak karena lingkungan yang berubah-ubah akan membahayakan perkembangan emosi bayi. Pengasuh yang berganti-ganti juga akan berpengaruh negatif pada perkembangan emosi anak. Menurut Bowlby (dalam Megawangi, 2003), normal bagi seorang bayi untuk mencari kontak dengan hanya satu orang (biasanya ibu) pada tahaptahap awal masa bayi. Kekacauan emosi anak yang terjadi karena tidak adanya rasa aman ini diduga oleh para ahli gizi berkaitan dengan masalah kesulitan makan pada anak. Tentu saja hal ini tidak kondusif bagi pertumbuhan anak yang optimal.

Kebutuhan akan stimulasi fisik dan mental juga merupakan aspek penting dalam pembentukan karakter anak. Tentu saja hal ini membutuhkan perhatian yang besar dari orang tua dan reaksi timbal balik antara ibu dan anaknya. Menurut pakar pendidikan anak, seorang ibu yang sangat perhatian (yang diukur dari seringnya ibu melihat mata anaknya, mengelus, menggendong, dan berbicara kepada anaknya) terhadap anaknya yang berusia usia di bawah enam bulan akan mempengaruhi sikap bayinya sehingga menjadi anak yang gembira, antusias mengeksplorasi lingkungannya, dan menjadikannya anak yang kreatif. 
Di sinilah tampaknya pola asuh di usia awal sangat menentukan pembentukan karakternya. Artinya, keberhasilan keluarga dalam menanamkan nilai-nilai kebajikan (karakter) pada anak sangat tergantung pada jenis pola asuh yang diterapkan orang tua pada anaknya. Pola asuh dapat didefinisikan sebagai pola interaksi antara anak dengan orang tua yang meliputi pemenuhan kebutuhan fisik (seperti makan, minum dan lain-lain) dan kebutuhan psikologis (seperti rasa aman, kasih sayang dan lain-lain), serta sosialisasi norma-norma yang berlaku di masyarakat agar anak dapat hidup selaras dengan lingkungannya. Dengan kata lain, pola asuh juga meliputi pola interaksi orang tua dengan anak dalam rangka pendidikan karakter anak.

Secara umum, Baumrind mengkategorikan pola asuh menjadi tiga jenis, yaitu; (1) Pola asuh authoritarian; (2) Pola asuh authoritative; (3) Pola asuh permissive. Tiga jenis pola asuh Baumrind ini hampir sama dengan jenis pola asuh menurut Hurlock juga Hardy \& Heyes yaitu: (1) Pola asuh otoriter, (2) Pola asuh demokratis, dan ( 3) Pola asuh permisif. Pola asuh otoriter mempunyai ciri orang tua membuat semua keputusan, anak harus tunduk, patuh, dan tidak boleh bertanya. Pola asuh demokratis mempunyai ciri orang tua mendorong anak untuk membicarakan apa yang ia inginkan. Dan pola asuh permisif mempunyai ciri orang tua memberikan kebebasan penuh pada anak untuk berbuat.

Melalui pola asuh yang dilakukan oleh orang tua, anak belajar tentang banyak hal, termasuk karakter. Tentu saja pola asuh otoriter (yang cenderung menuntut anak untuk patuh terhadap segala keputusan orang tua) dan pola asuh permisif (yang cenderung memberikan kebebasan penuh pada anak untuk berbuat) sangat berbeda dampaknya dengan pola asuh demokratis (yang cenderung mendorong anak untuk terbuka, namun bertanggung jawab dan mandiri) terhadap hasil pendidikan karakter anak. Jenis pola asuh yang diterapkan oleh orang tua terhadap anaknya menentukan keberhasilan pendidikan karakter anak oleh keluarga.

Pola asuh otoriter cenderung membatasi perilaku kasih sayang, sentuhan, dan kelekatan emosi orangtua-anak sehingga antara orang tua dan anak seakan memiliki dinding pembatas yang memisahkan "si otoriter" (orang tua) dengan "si patuh" (anak). Studi yang dilakukan oleh Fagan (dalam Badingah, 1993) menunjukan bahwa ada keterkaitan antara faktor keluarga dan tingkat kenakalan 
keluarga, di mana keluarga yang broken home, kurangnya kebersamaan dan interaksi antar keluarga, dan orang tua yang otoriter cenderung menghasilkan remaja yang bermasalah. Pada akhirnya, hal ini akan berpengaruh terhadap kualitas karakter anak.

Pola asuh permisif yang cenderung memberi kebebesan terhadap anak untuk berbuat apa saja sangat tidak kondusif bagi pembentukan karakter anak. Bagaimana pun anak tetap memerlukan arahan dari orang tua untuk mengenal mana yang baik dan mana yang salah. Dengan memberi kebebasan yang berlebihan, apalagi terkesan membiarkan, akan membuat anak bingung dan berpotensi salah arah. Pola asuh demokratis tampaknya lebih kondusif dalam pendidikan karakter anak. Hal ini dapat dilihat dari hasil penelitian yang dilakukan oleh Baumrind yang menunjukkan bahwa orangtua yang demokratis lebih mendukung perkembangan anak terutama dalam kemandirian dan tanggungjawab. Sementara, orangtua yang otoriter merugikan, karena anak tidak mandiri, kurang tanggungjawab serta agresif, sedangkan orangtua yang permisif mengakibatkan anak kurang mampu dalam menyesuaikan diri di luar rumah.

Menurut Arkoff (dalam Badingah, 1993), anak yang dididik dengan cara demokratis umumnya cenderung mengungkapkan agresivitasnya dalam tindakantindakan yang konstruktif atau dalam bentuk kebencian yang sifatnya sementara saja. Di sisi lain, anak yang dididik secara otoriter atau ditolak memiliki kecenderungan untuk mengungkapkan agresivitasnya dalam bentuk tindakantindakan merugikan. Sementara itu, anak yang dididik secara permisif cenderung mengembangkan tingkah laku agresif secara terbuka atau terang-terangan. Menurut Middlebrook (dalam Badingah, 1993), hukuman fisik yang umum diterapkan dalam pola asuh otoriter kurang efektif untuk membentuk tingkah laku anak karena:

(a) menyebabkan marah dan frustasi (dan ini tidak cocok untuk belajar);

(b) adanya perasaan-perasaan menyakitkan yang mendorong tingkah laku agresif;

(c) akibat-akibat hukuman itu dapat meluas sasarannya, misalnya anak menahan diri untuk memukul atau merusak pada waktu ada orang tua tetapi segera melakukan setelah orang tua tidak ada;

(d) tingkah laku agresif orangtua menjadi model bagi anak. 
Hasil penelitian Rohner (dalam Megawangi, 2003) menunjukkan bahwa pengalaman masa kecil seseorang sangat mempengaruhi perkembangan kepribadiannya (karakter atau kecerdasan emosinya). Penelitian tersebut, yang menggunakan teori PAR (Parental Acceptance-Rejection Theory), menunjukkan bahwa pola asuh orang tua, baik yang menerima (acceptance) atau yang menolak (rejection) anaknya, akan mempengaruhi perkembangan emosi, perilaku, sosialkognitif, dan kesehatan fungsi psikologisnya ketika dewasa kelak. Dalam hal ini, yang dimaksud dengan anak yang diterima adalah anak yang diberikan kasih sayang, baik secara verbal (diberikan kata-kata cinta dan kasih sayang, kata-kata yang membesarkan hati, dorongan, dan pujian), maupun secara fisik (diberi ciuman, elusan di kepala, pelukan, dan kontak mata yang mesra). Sementara, anak yang ditolak adalah anak yang mendapat perilaku agresif orang tua, baik secara verbal (kata-kata kasar, sindiran negatif, bentakan, dan kata-kata lainnya yang dapat mengecilkan hati), ataupun secara fisik (memukul, mencubit, atau menampar).

Sifat penolakan orang tua dapat juga bersifat indifeerence atau neglect, yaitu sifat yang tidak memperdulikan kebutuhan anak baik fisik maupun batin, atau bersifat undifferentiated rejection, yaitu sifat penolakan yang tidak terlalu tegas terlihat, tetapi anak merasa tidak dicintai dan diterima oleh orang tua, walaupun orang tua tidak merasa demikian. Hasil penelitian Rohner menunjukkan bahwa pola asuh orang tua yang menerima membuat anak merasa disayang, dilindungi, dianggap berharga, dan diberi dukungan oleh orang tuanya. Pola asuh ini sangat kondusif mendukung pembentukan kepribadian yang pro-sosial, percaya diri, dan mandiri namun sangat peduli dengan lingkungannya. Sementara itu, pola asuh yang menolak dapat membuat anak merasa tidak diterima, tidak disayang, dikecilkan, bahkan dibenci oleh orang tuanya. Anak-anak yang mengalami penolakan dari orang tuanya akan menjadi pribadi yang tidak mandiri, atau kelihatan mandiri tetapi tidak mempedulikan orang lain. Selain itu anak ini akan cepat tersinggung, dan berpandangan negatif terhadap orang lain dan terhadap kehidupannya, bersikap sangat agresif kepada orang lain, atau merasa minder dan tidak merasa dirinya berharga.

Dari paparan di atas jelas bahwa jenis pola asuh yang diterapkan orang tua kepada anaknya sangat menentukan keberhasilan pendidikan karakter anak. 
Kesalahan dalam pengasuhan anak akan berakibat pada kegagalan dalam pembentukan karakter yang baik. Menurut Megawangi (2003) ada beberapa kesalahan orang tua dalam mendidik anak yang dapat mempengaruhi perkembangan kecerdasan emosi anak sehingga berakibat pada pembentukan karakternya, yaitu;

1. Kurang menunjukkan ekspresi kasih sayang baik secara verbal maupun fisik.

2. Kurang meluangkan waktu yang cukup untuk anaknya.

3. Bersikap kasar secara verbal, misainya menyindir, mengecilkan anak, dan berkata-kata kasar.

4. Bersikap kasar secara fisik, misalnya memukul, mencubit, dan memberikan hukuman badan lainnya.

5. Terlalu memaksa anak untuk menguasai kemampuan kognitif secara dini.

6. Tidak menanamkan "good character' kepada anak.

Dampak yang ditimbulkan dari salah asuh seperti di atas, menurut Megawangi akan menghasilkan anak-anak yang mempunyai kepribadian bermasalah atau mempunyai kecerdasan emosi rendah. Anak menjadi acuh tak acuh, tidak butuh orang lain, dan tidak dapat menerima persahabatan. Karena sejak kecil mengalami kemarahan, rasa tidak percaya, dan gangguan emosi negatif lainnya. Ketika dewasa ia akan menolak dukungan, simpati, cinta dan respons positif lainnya dari orang di sekitarnya. la kelihatan sangat mandiri, tetapi tidak hangat dan tidak disenangi oleh orang lain.

Secara emosiol tidak responsif, dimana anak yang ditolak akan tidak mampu memberikan cinta kepada orang lain. Kemudian melahirkan perilaku agresif, yaitu selalu ingin menyakiti orang baik secara verbal maupun fisik. Menjadi minder, merasa diri tidak berharga dan berguna serta selalu berpandangan negatif pada lingkungan sekitarnya, seperti rasa tidak aman, khawatir, minder, curiga dengan orang lain, dan merasa orang lain sedang mengkritiknya.

Ketidakstabilan emosional akan melahirkan sikap tidak toleran atau tidak tahan terhadap stress, mudah tersinggung, mudah marah, dan sifat yang tidak dapat dipresiatif oleh orang lain. Adanya ketidakseimbangan antara perkembangan emosional dan intelektual. Dampak negatif lainnya dapat berupa mogok belajar, dan bahkan dapat memicu kenakalan remaja, tawuran, dan lainnya. Orang tua yang tidak memberikan rasa aman dan terlalu menekan anak, akan membuat anak 
merasa tidak dekat, dan tidak menjadikan orang tuannya sebagai "role model" Anak akan lebih percaya kepada "peer group"nya sehingga mudah terpengaruh dengan pergaulan negatif. Oleh karena itu, setiap keluarga harus memiliki kesadaran bahwa pendidikan karakter anak sangat tergantung pada proses pendidikan karakter dalam keluarga

\section{KESIMPULAN}

Keluarga adalah lingkungan pertama dan utama bagi seorang anak manusia. Di dalam keluarga seorang anak dibesarkan, mempelajari cara-cara pergaulan yang akan dikembangkannya kelak di lingkungan kehidupan sosial yang ada di luar keluarga. Dengan perkataan lain, di dalam keluarga seorang anak dapat memenuhi kebutuhan-kebutuhannya, baik kebutuhan fisik, psikis maupun sosial, sehingga mereka dapat tumbuh dan berkembang dengan baik. Di samping itu pula, seorang anak memperoleh pendidikan yang berkenaan dengan nilai-nilai maupun norma-norma yang ada dan berlaku di masyarakat ataupun dalam keluarganya sendiri serta cara-cara untuk menyesuaikan diri dengan lingkungannya.

Secara sederhana dapat dikemukakan bahwa fungsi keluarga adalah menstabilkan situasi keluarga dalam arti stabilisasi situasi ekonomi keluarga. Kemudian fungsi keluarga juga mendidik dan memelihara fisik dan psikis keluarga, termasuk kehidupan religius. Selanjutny, mengenai fungsi keluarga, khususnya tanggung jawab orang tua terhadap anaknya.Tanggung jawab orang tua ialah memenuhi kebutuhan-kebutuhan si anak baik dari sudut organis-psikologis, antara lain, makanan, maupun kebutuhan-kebutuhan psikis seperti kebutuhankebutuhan akan perkembangan, kebutuhan intelektual melalui pendidikan, kebutuhan rasa dikasihi, dimengerti dan rasa aman melalui perawatan asuhan ucapan-ucapan dan perlakuan

Keluarga merupakan lembaga pendidikan bersifat informal, yang pertama dan utama dialami oleh anak serta lembaga pendidikan yang bersifat kodrati orang tua bertanggung jawab memelihara, merawat, melindungi, dan mendidik anak agar tumbuh dan berkembang dengan baik. Di sini peranan oang tua terutama ibu sangatlah berpengaruh terhadap perkembangan anak tersebut. Pendidikan keluarga disebut pendidikan utama karena di dalam lingkungan ini segenap 
potensi yang dimiliki manusia terbentuk dan sebagian dikembangkan. Bahkan ada beberapa potensi yang telah berkembang dalam pendidikan keluarga.

Anak-anak akan tumbuh menjadi pribadi yang berkarakter apabila dapat tumbuh pada lingkungan yang berkarakter, sehingga fitrah setiap anak yang dilahirkan suci dapat berkembang segara optimal. Pendidikan karakter harus dimulai dari keluarga untuk membangun kepribadian bangsa yang mulia. Untuk mencapai karakter anak yang diharapkan oleh orang tua, pola asuh yang diberikan keluarga kepada anak-anak sangat berkaitan erat dengan karakter anak dalam tumbuh kembangnya. Karakter tersebut akan terbawa sampai dewasa bahkan sampai mereka membentuk keluarga sendiri.

Sebaliknya, kegagalan keluarga dalam membentuk karakter anak akan berakibat pada tumbuhnya masyarakat yang tidak berkarakter. Oleh karena itu, setiap keluarga harus memiliki kesadaran bahwa pembentukan karakter anak sangat tergantung pada pendidikan karakter di rumah. Lebih jauh, Megawangi (2003) menyebutkn setidaknya ada tiga kebutuhan dasar anak yang harus dipenuhi, yaitu maternal bonding, rasa aman, dan stimulasi fisik dan mental. 


\section{DAFTAR PUSTAKA}

Badingah, S. 1993. "Agresivitas Remaja Kaitannya dengan Pola Asuh, Tingkah Laku Agresif Orang Tua dan Kegemaran Menonoton Film Keras". Program Studi Psikologi-Pascasarjana, UI. Depok

Baron, R. A dan Donn Byrne, 2003. Psikologi Sosial, Jakarta: Erlangga

Elkind, David H. dan Sweet, Freddy. How to Do Character Education. Artikel yang diterbitkan pada bulan September/Oktober 2004.

Lickona, Thomas, 1991. Educating for Character: Hoe Our School Can Do Teach Respect and Responsibility, New York; Brantam Book.

Lickona, Thomas, 1999. Eleven Principle of Effective Character, Scholastic Early Childhood To day, November/December 1998, 13.1, PreQuest Education Journals.

Lickona, Thomas, Schaps, Eric, dan Lewis, Catherine, 2007. Eleven Principles of Effective Character Education. Character Education Partnership.

Megawangi, Ratna. 2003. Pendidikan Karakter untuk Membangun Masyarakat Madani, IPPK Indonesia Heritage Foundation.

Sairin, Weinata. 2001. Pendidikan yang Mendidik. Jakarta: Yudhistira.

Sumber Internet:

http://alenmarlissmpn1gresik. wordpress.com/2010/10/03/ manfaat-karakteristikpendidikan-bagi-guru-untukmembangunperadaban bangsa/ 